\title{
IDOSOS EM AULA POR RECURSOS TECNOLÓGICOS ${ }^{12}$
}

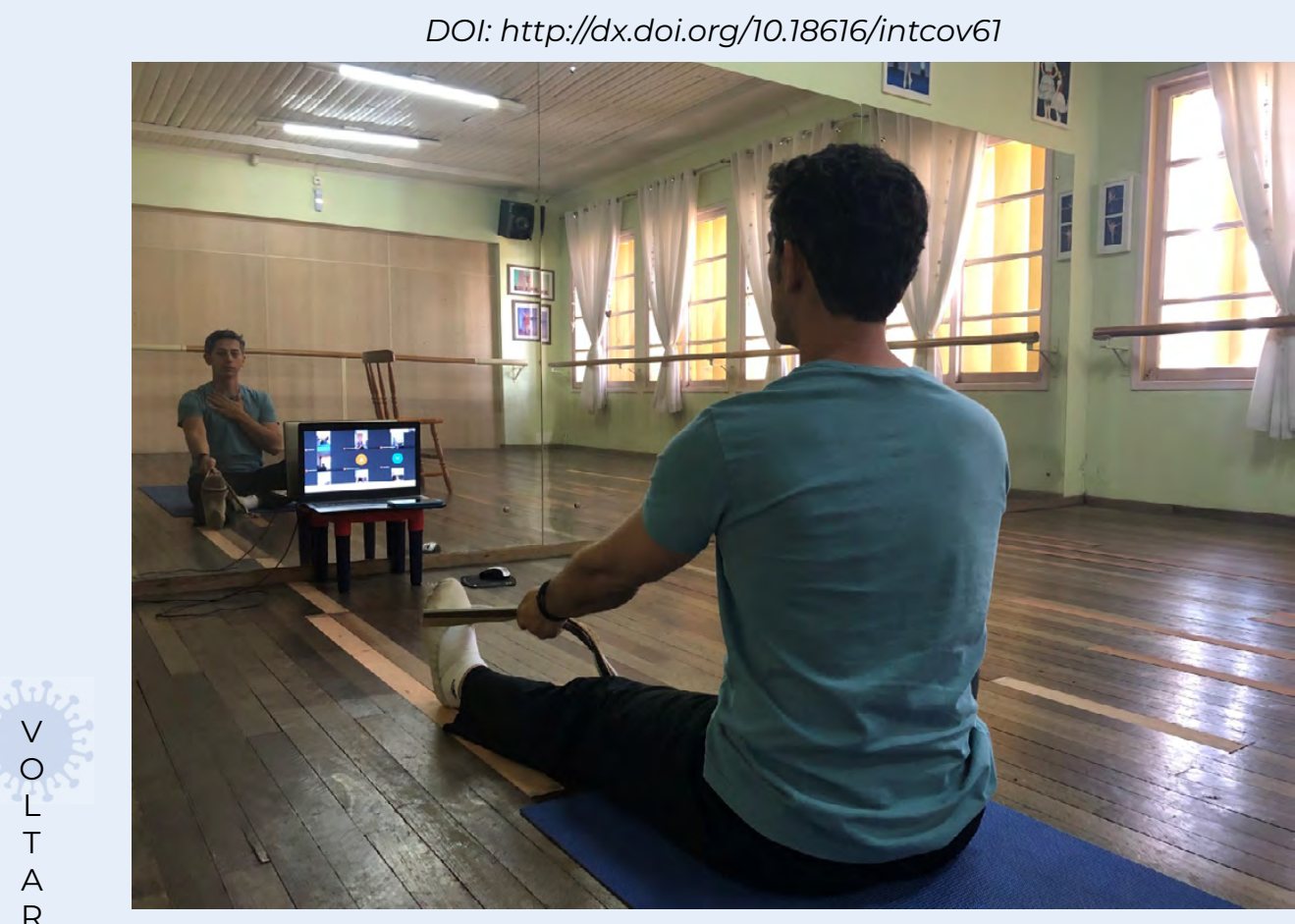

Créditos: Anderson Felisberto Cristiano.

A

O

12 Em tempos da covid-19, os idosos utilizaram-se da resiliência com a ajuda dos profissionais da área da educação e da saúde, ressignificam-se aprendendo a utilizar plataformas on-line para dar continuidade em suas atividades sociais. 